\title{
Inclusion of students with autism spectrum disorder in the Jordanian regular classrooms: Teachers' perspectives
}

\author{
Mohammad Abed Sakarneh ${ }^{\mathrm{a}}$, Hiam Jameel Katanani ${ }^{\mathrm{a}}$, \\ Azeez Ahmad Alrahamneh ${ }^{\mathrm{b}}$ \\ a Al Balqa Applied University - Princess Rahama University College, Al-Salt, Jordan \\ ${ }^{b}$ Al Balqa Applied University - Al-Salt College for Human Sciences, Al-Salt, Jordan
}

\begin{abstract}
Introduction. This study focuses on the relevance of inclusion for students with autism spectrum disorder (ASD) in the regular classroom. This issue has achieved international recognition with recommendations in most countries that the students should be given the same opportunities as those without disabilities. The case of Jordanian teachers in Amman is selected in this study. Objectives. It specifically aims at investigating the teachers' perspectives on inclusion of students with ASD in Jordanian regular classrooms. Methods. The issue is evaluated using a qualitative study design where nine teachers were interviewed virtually. Results. The findings indicated the need for better training and skills development in specific aspects and needs of students with ASD. Providing teachers with training as well as materials and financial support is necessary for supporting inclusive learning. The teachers also report significant limitations in how inclusion of ASD students is supported in Jordan. The perspectives towards inclusion of ASD students in Jordan show that they have low confidence and self-esteem in dealing with these students and organizing inclusive classrooms due to inadequate training and experience. Conclusion. The findings of this study indicate the need for policy makers in Jordan to consider providing specific training to their general education teachers.
\end{abstract}

Keywords: autism spectrum disorder, inclusive education, regular classrooms, teachers' perspectives

\section{Introduction}

Autism Spectrum Disorder (ASD) is "neurodevelopment disorder that is characterized by difficulties with social communication and social interaction and restricted and repetitive patterns in behaviors, interests, and activities" (APA, 2013, p. 50). It involves a wide range of abilities and disabilities that 
students or individuals can have and that may influence learning and cognitive function. Students with ASD have unique needs for learning, communication and social skills (Sakarneh et al., 2019). As a result, it is difficult to help these students achieve their full potential and bring out the best in them. Students with ASD deserve to learn in the least restrictive environment where they gain skills to help them function effectively in society while at the same time getting the necessary assistance to learn effectively in the classroom (Reupert et al., 2015). A general education teacher has to consider the challenges of teaching students with ASD.

ASD as a learning disorder has gained global attention owing to the increasing levels of diagnosis. For example, Centers for Disease Control and Prevention data shows that the number of children with ASD in the United States in 2014 was 1 in 68 (CDC, 2014). Jordan is a signatory to the UN Convention on the Rights of Persons with Disabilities (CRPD), which is meant to make sure that the rights of individuals with disabilities are met. It also seeks to ensure that persons with disabilities can fully participate in life and have equal opportunities with their peers (Higher Council for the Rights of Persons with Disabilities, 2017; Pellecchia et al., 2015; Sakarneh, 2014). However, the gap between theory and practice in this area has been difficult to bridge in order to ensure that people with disabilities get the same opportunities.

The number of children diagnosed with ASD at the global level has increased their inclusion in regular classrooms. The high prevalence rates of ASD and the shift from an exclusive education to an inclusive paradigm have created a significant need for teachers and policy makers to identify effective ways of making classes more inclusive and identifying the potential barriers and enablers for these students (Pugach et al., 2014). However, some literature argues that inclusive education does not have practical applications when it comes to inclusion of students with ASD in regular classroom (Chhabra et al., 2010). Learners with ASD require to be exposed to educational instruction that can help them improve functioning in the society. It is challenging to deal with ASD students and many teachers are afraid to teach them because they lack knowledge and support from administrators (Chung et al., 2015). Few teachers including those with a background in special education are specifically trained to manage students with ASD in their classrooms. Many teachers argue that they would be willing to include students with ASD in their classrooms if they were effectively trained (Chung et al., 2015). This indicates that they may feel unprepared to meet the need of these students. Teachers with formal training in special education have been found to have more confidence in dealing with ASD students than general education teachers (Leach \& Duffy, 2009).

According to Denning \& Moody (2013), students with ASD have specific needs that significantly influence their success in inclusive classes in different ways. These include the fact that they have difficulties engaging in the class due 
to the challenges they have in understanding concepts and working within the class environment to filter out necessary information (Sakarneh et al., 2019). Another critical issue is the lack of motivation among students with ASD that is apparent through task avoidance and disruptive behaviors in the classroom such as crying and running away (Sakarneh et al., 2019). Such studies indicate that the ability of ASD students to gain and maintain attention is significantly limited, which is shown through the challenges in learning new materials (Sakarneh et al., 2019). This is especially difficult when the tasks in question require quick processing speed or cognitive flexibility. Students with ASD have difficulties completing their work including submitting assignments and meeting expectations (Chandler-Olcott \& Kluth, 2009). These issues can be addressed in the classroom through universal design for learning and adaptation to the learning environment (Chandler-Olcott \& Kluth, 2009).

There is a global pursuit of inclusion with scholars and other stakeholders seeking ways of ensuring that the concepts can be effectively applied in practice. One of the challenges in this case is the fact that the development of a universally acceptable definition is illusive including what counts as evidence of its practice. Some of the critical considerations are cited in implementing an inclusive classroom, indicating the valuation of each learner as a member of the regular classroom culture (Ballard, 2012). All members and groups constitute presence, achievement and active participation. The focus is on identifying the needs of all learner groups and determining the barriers in their active participation and achievement (Majoko, 2018). Involvement of all learners and their families in the regular classroom requires identifying the least restrictive environment as well as adapting and delivering content to the learner with special needs.

Majoko (2018) found that teachers were optimistic about inclusion of students with ASD in the mainstream classrooms although there was uncertainty about it. They considered it to be highly critical in line with social justice and equity considerations. Social and behavioral challenges, communication and curriculum were critical issues confronting teachers. Humphrey and Symes (2013) found that teachers who have ASD students in their classes experienced tensions in their efforts to manage the emerging challenges. This included anxiety that the teachers feel regarding their ability to meet their specific needs without compromising the other students in the classroom. The tensions and how the teachers negotiate them can have a significant impact on the quality of the teacher-student interactions or relations (Humphrey \& Symes, 2013; Sakarneh, 2020). Teaching students with ASD may require applying approaches that are unfamiliar to a regular teacher (Humphrey \& Symes, 2013; Sakarneh, 2020). Additionally, the necessary strategies may differ for individual students depending on their age, classroom setting, and the level of learning disability. Lindsay et al. (2014) argued that the involvement of students with ASD in the conventional classroom can stimulate effective learning as well as development 
and perception of acceptance in the society. To fully integrate the learners in the classrooms, the equalization of educational opportunities is essential. Learners in inclusive classrooms are likely to have better educational objectives and social support networks compared to those in special classrooms (Mandell et al., 2013).

There has been limited research on the issue of inclusion for learners with special needs in Jordan. For example, Abu-Hamour and Muhaidat (2014) focused on the attitudes of parents. They assessed whether the functional level of ASD and demographic variables influenced parental attitudes. They found that the functional level of ASD and parental educational level were significant factors influencing inclusion outcomes. Other studies have indicated that the implementation of inclusive education for ASD students in Jordan is strongly influenced by issues such as teachers' confidence due to their knowledge, qualifications, preparation and awareness of the inclusion policy in the country (Sakarneh, 2020; Sakarneh et al., 2016). The need to further understand teachers' perspectives is critical in ensuring that the needs of the students are effectively met. Within this argument, the current study focuses on the perspectives of teachers as the most important stakeholders in the process of inclusion for students with ASD in regular classroom who can create more inclusive classrooms for students with ASD. Therefore, this study intends to answer the following research question: what are teachers' perspectives on inclusion of students with autism spectrum disorder in Jordanian regular classrooms?

\section{Methods}

This research focused on evaluating teachers' perspective on the inclusion of students with ASD in regular classrooms. In order to identify the critical issues relevant to the students with ASD in regular classroom, a qualitative study approach was adopted. This required applying an exploratory approach as the researchers worked with the teachers who were involved in the specific condition of interest (Creswell, 2013). The researchers adopted an interpretivist approach as the critical issue is to use the subjective views and in-depth information of the participants to identify the key themes in their experiences with ASD students in regular classroom.

In line with the study objective in assessing the perspectives of teachers involved in inclusive classrooms with ASD students, the qualitative research design was considered to be the most effective. The focus was to assess teachers' views and perspectives on the inclusive learning practice and theory. By focusing on the teachers who have practical experience in having ASD students in their inclusive classrooms, abstract generalizations and conceptualization would be developed. The experiences of teachers in working with ASD students in inclusive classrooms were considered as being highly critical in answering research question. The relevant data was collected from teachers and used to generate themes and sub themes that could explain the issue. 


\section{Sample}

Virtual meetings with nine participants were undertaken over a period of 14 days and the demographic characteristics of the teachers are presented in Table 1 below.

\section{Table 1}

Demographic Characteristics of the Participants

\begin{tabular}{llccc}
\hline & Gender & Experience & $\begin{array}{c}\text { Formal Training in } \\
\text { Special Education }\end{array}$ & Education Level \\
\hline A & Female & $>10$ & No & Diploma \\
B & Male & $5-10$ & Yes & Masters \\
C & Male & $5-10$ & No & Certificate \\
D & Female & $<5$ & Yes & Diploma \\
E & Male & $5-10$ & Yes & Bachelors \\
F & Female & $<5$ & No & Certificate \\
G & Female & $<5$ & Yes & Diploma \\
H & Male & $5-10$ & Yes & Bachelors \\
I & Female & $>10$ & Yes & Masters \\
\hline
\end{tabular}

Most of the participants were formally trained in special education, accounting for six teachers of the sample compared to those without such formal training. Two of the participants had more than 10 years of teaching experience while four had between five and 10 years of experience in the field. The other three had less than five years of experience. The sample also consisted of individuals who had at least a diploma in education, indicating that they had the requisite knowledge of teaching and handling their students.

\section{Procedure}

The researchers visited the Ministry of Education (special education directorate) to identify the schools which had inclusive classrooms with ASD students. The directorate provided the authors with names of four schools (two are private and the other two are public). In order to obtain the relevant research data, the participants were sampled using convenience sampling by identifying teachers from elementary schools within Amman Governorate in Jordan. All identified schools were visited and the contacts of the identified teachers were obtained from the schools administrations. After identifying the relevant schools and classes by the administration, the teachers were contacted and notified about the study. Also, the authors explained the purpose of the study and the participants were free to withdraw from the interview at any time. The request to participate including informed consent form and information sheet was sent to all teachers. 


\section{Data Collection}

The research data was collected using in-depth face to face interviews with teachers and evaluated using a phenomenological research design where the interest was to assess the inclusive classroom as a phenomenon in question and evaluate teachers' expectations including the challenges they faced and practice-based opportunities. Semi-structured interview was used guided by questions derived from reviewing the related literature.

Face to face interviews were conducted virtually at the convenience of the participants using Google Meet. They lasted 45 minutes and involved questions for seeking additional information and clarification from the participants. Nine teachers were included in the interviews to gather the relevant data and identify the critical issues.

\section{Data Analysis}

Data coding and analysis was undertaken using content analysis through Qualitative Data Analysis Program - Atlas.ti. Coding the main themes was done by the authors and another independent coder with their results being compiled and discussed to come up with the harmonized themes and sub themes (Bailey, 2008).

\section{Results}

The following themes were extracted from the analysis:

\section{Definition of Inclusivity}

The definition of inclusivity was evaluated by the participants through assessing their awareness of practice and legislation. The teachers generally indicated that the concept required them to have students with disabilities and those without disabilities in the same classes to ensure equity. One teacher said "these kids are like my kids... regardless of what their abilities are; it is not their fault... if it is my choice, I would not leave them for a moment I am like their mothers". Another teacher simply defined inclusivity as she said "the inclusivity is a process of placing children with ASD with their normal peers in the regular classroom". The responses showed the need to have students with disabilities in regular classrooms and to take responsibility in addressing their specific needs. One of the key issues in the findings was that some teachers considered it as a process while for others it was a learning environment provided to the students with ASD. One teacher said "it is shame to leave those kids at home or centers for children with disabilities, but they will take me a lot of time and effort”.

Definition and awareness of inclusive education policies were considered as related concepts. Most of the teachers reported that they were aware of the policies although they did not quite understand how to implement them. One participant argued that inclusive education policies were too far from their 
practical environment. One teacher said "My dears... we do not want theories... we need practice... in the documents [she means policy documents] they [educational supervisors] ask us to include those kids in the regular classrooms and they never visit us and observe what we do about those kids... nobody asks about them... they leave it up to our consciences". Another teacher reported that inclusive education in her school was not clear and there were no supportive processes to enhance its implementation. Absence of effective strategies for activities to be implemented in supporting students with ASD was cited as a major challenge and discrepancy between practice and theory.

\section{Teacher Preparation}

The issue of teacher preparedness and preparation in implementing inclusive education for ASD students was assessed. The participants were asked about the adequacy of their preparation courses and whether these differed for general and special education teachers. A common issue among the general education teachers was a lack of preparation for effectively implementing inclusive classrooms. They argued that specific training on how to implement inclusive classrooms was necessary in their post-service training. This was especially relevant since some reported not having any knowledge of what students with ASD need in order to learn effectively. One teacher said "I do not have enough training on how to treat those kids!!!... I have one child in my class hitting other students and I do not know how to deal with that!!! I need a shadow teacher to help me". General teachers reported that they only had general information about including these students in their classes. They felt that there were a lot of things they were supposed to learn in their pre- and post-service training to ensure that they could effectively implement inclusive learning. Another teacher said "We do not know what special education is and what inclusivity is ... it is the first time I see students with special needs!!! I sympathize with them, but there is not enough to offer them!!! I hope that trained teachers and specialists in special education will help me".

The teachers including those with special education training reported that there was a need for preplanned programs on the implementation of inclusive education for ASD students. One of the teachers' interesting themes was the need for university curriculum revision and restructuring on teacher training. Participant $E$ indicated the need for curriculum restructuring to ensure that they could effectively implement inclusive classrooms for students with ASD. Participant B who had training in special education argued that he felt the university programs were rather inappropriate and provided teachers with insufficient information about implementing inclusive classrooms for students with ASD and other disabilities. A lack of specific education skill for managing the inclusive classroom was a key barrier that the teachers identified in the implementation. 


\section{Necessity of Additional Support}

In addition to the theme of additional training necessary for teachers to enable them to manage inclusive classrooms and address the learning needs of students with ASD, there was the theme of additional support and implementation of international best practices. One participant who had training in special education reported that there was a need for the education system and schools in the country to follow the developments in other countries. She argued that the education system and curriculum should provide programs on how the strategies and frameworks have been implemented in other countries.

The need for policy support and input from relevant stakeholders would be very important in making inclusive classrooms successful. Apart from training, education provided at universities and programs offered by the government should be based on the strategies of other countries that have succeeded in making students with ASD a part of regular classrooms. One participant reported that if preparation for inclusive classrooms was made compulsory in the field, they would be more willing to consider it. Adapting strategies for teachers and focusing on the specific needs of students would be very important in ensuring success.

\section{Resources}

Here we focused on the existing resources for Jordanian teachers to support inclusive classrooms with ASD students. The distinction in perceptions between special and general education teachers in Jordan was an important aspect of the research. The teachers reported that there were a lot of things needed in implementing inclusive education. One participant indicated that it was not easy to organize an inclusive classroom including providing the necessary support to teachers and students. For inclusive education to be applicable and successful, the participants highlighted that they needed experience, supportive environment, financial resources, and greater support. The issue of administrative support for teachers was cited as a key element of the resources required for implementation. One teacher commented "We are poorly-paid and we are required to work a lot, how do you want me to work with students with different abilities?!!!. My time at school is not enough... I have to complete my work at home, but I have my children and they need to take care of me.... If my salary was acceptable, I would employ a worker and do my work to the fullest".

According to one participant, it was awkward to talk about needing support from other staff since they were also not prepared or skilled. One general education teacher reported that the practice of inclusive education was not being implemented in her school. The teachers' perspective in this case was that inclusivity for students with ASD was not only about having them in the regular 
classroom, but also about providing them with the necessary resources such as extra support for children with and without disabilities to ensure that they can learn. Adequate resources should be provided alongside what is espoused in the law. Two teachers in the school who had training in special education reported that their administrators were qualified in providing the required support and promoting their efforts towards creating inclusive classrooms. The materials and physical support necessary for students with disabilities have to be made available because they complement the efforts of teachers. Having support and training for teachers would be irrelevant without physical resources needed. According to most of the teachers, there was a lack of the physical support needed for addressing the needs of students with ASD. Providing and allocating these financial resources was a challenge for schools.

\section{Attitudes}

The attitudes of teachers towards their confidence in delivering inclusive education for students with ASD were reported to be associated with their level of knowledge and training. A key theme here was that most of the participants indicated that they would be more confident about their capacity to teach inclusive classrooms if they had the requisite training. Most teachers reported that they lacked confidence in their capacity to work with ASD students and effectively include them in regular classrooms. It was apparent that most teachers had low self-esteem regarding their capacity to teach students with ASD in their regular classrooms.

\section{Discussion}

The results of the interviews indicate that the case of Jordanian teachers in providing inclusive education faces significant practical challenges. This result is consistent with results of previous studies (Chhabra et al., 2010; Chung et al., 2015; Leach \& Duffy, 2009; Pugach et al., 2014; Sakarneh, 2020). Students with ASD require a lot of support from their teachers in the classroom to ensure that they achieve the expected learning outcomes (Fettig et al., 2011; Sakarneh, 2020). Visual support and other resources needed for students have to be provided in a deliberate manner to ensure that they support inclusive classrooms. The success and challenges of inclusion for students with ASD are mainly associated with the level of teacher training. In the case of Jordan, it is apparent that there is legislative support for inclusive learning, but there is a lack of the policy environment including the level of teacher training. Teachers cite a lack of the necessary training on how to work with ASD students in their regular classes (Koegel et al., 2010; Sakarneh, 2020).

Knowledge of the legislation is very high among teachers although there is a lot of concern about the practical supports provided to students and 
teachers. The teachers indicate the need for effective training programs and university curriculum restructuring on teacher training. Teacher preparation is heavily lacking alongside the additional support and resources required for addressing the inclusivity need of students with ASD. These results are similar to the results of previous research studies (Chandler-Olcott \& Kluth, 2009; Majoko, 2018; Sakarneh, 2020). Students with ASD require additional support including materials and financial resources. These issues can play a major role in limiting the teacher and school capacity to effectively implement inclusive classrooms. The attitudes of Jordanian teachers towards inclusion of students with ASD in the classroom indicate very low self-esteem. The teachers cite a lack of training and experience in dealing with ASD students as a key barrier to inclusion. This is similar to the views of Hintz et al. (2015) and Khochen \& Radford (2012) regarding the attitudes of teachers and administrators towards inclusion based on their training level.

\section{Limitations}

Due to the methodological limitations in relation to the study sample and methods of data collection and analysis, the results of the current study cannot be generalized unless the same conditions are applied.

\section{Conclusion}

The findings of this study indicate the need for policy makers in Jordan to consider providing specific training to their general education teachers. The teachers should be provided with information and knowledge on how to deal with ASD students in the regular classroom. Theory on inclusion of ASD students in the regular classroom is based on the need to ensure equity for the students by allowing them access to the same resources and environment. Jordanian teachers' perspective on this issue shows their relevance as system implementers. However, they cannot achieve what is expected if they are not provided with the necessary knowledge or skills. Additionally, they indicate the need to get additional support from schools and government in order to ensure that students with ASD can gain as much experience as those without disabilities and get to learn as required. Inclusion of best practices from the rest of the world is important in ensuring that students with ASD in Jordan will be able to achieve similar outcomes and that the strategies can be implemented successfully. 


\section{References}

Abu-Hamour, B., \& Muhaidat, M. (2014). Parents' attitudes towards inclusion of students with autism in Jordan. International Journal of Inclusive Education, 18(6), 567-579. doi.org/10.1080/13603116.2013.802026

American Psychiatric Association (APA). (2013). Diagnostic and statistical manual of mental disorders: Fifth edition DSM- $V$. Publisher.

Bailey, R. A. (2008). Design of comparative experiments. Cambridge University Press Cambridge. https://doi.org/10.1017/CBO9780511611483

Ballard, K. (2012). Inclusion and social justice: Teachers as agents of change. In S. Carrington, \& J. Macarthur (Eds.), Teaching in inclusive school communities (pp. 65-87). John Wiley \& Sons.

Centers for Disease Control and Prevention (CDC). (2014). CDC estimates 1 in 68 children has been identified with autism spectrum disorder. https://www.cdc.gov/media/ releases/2014/p0327-autism-spectrum-disorder.html

Chandler-Olcott, K., \& Kluth, P. (2009). Why everyone benefits from including students with autism in literacy classrooms. The Reading Teacher, 62(7), 548-557. https://doi. org/10.1598/RT.62

Chhabra, S., Srivastava, R., \& Srivastava, I. (2010). Inclusive education in Botswana: The perceptions of school teachers. Journal of Disability Policy Studies, 20(4), 219-228. https://doi.org/10.1177/1044207309344690

Chung, W., Edgar-Smith, S., \& Palmer, R. (2015). An examination of in-service teacher attitudes toward students with autism spectrum disorder: Implications for professional practice. Current Issues in Education, 18(2), 1-10.

Creswell, J. W. (2013). Qualitative inquiry and research design: Choosing among five approaches (3rd ed.). Sage.

Denning, C. B., \& Moody, A. K. (2013). Supporting students with autism spectrum disorders in inclusive settings: Rethinking instruction and design. Electronic Journal for Inclusive Education, 3(1), Article 6.

Fettig, A., Meadan, H., Michna, A., Ostrosky, M. M., \& Triplett, B. (2011). Using visual supports with young children with autism spectrum disorder. Teaching Exceptional Children, 43(6), 28-35. https://doi.org/10.1177/004005991104300603

Higher Council for the Rights of Persons with Disabilities. (2017). Law on the Rights of Persons with Disability. http://hcd.gov.jo/en

Hintz, A.-M., Urton, K., Krull, J., Wilbert, J., \& Hennemann, T. (2015). Teachers' perceptions of opportunities and threats concerning inclusive schooling in Germany at an early stage of inclusion: Analyses of a mixed methodology approach. Journal of Cognitive Education and Psychology, 14(3), 357-374. https://doi.org/10.1891/19458959.14.3.357

Humphrey, N., \& Symes, W. (2013). Inclusive education of pupils with autistic spectrum disorders in secondary mainstream schools: Teacher attitudes, experience and knowledge. International Journal of Inclusive Education, 17(1), 32-46. https://doi. org/10.1080/13603116.2011.580462

Khochen, M., \& Radford, J. (2012). Attitudes of teachers and head-teachers towards inclusion in Lebanon. International Journal of Inclusive Education, 16(2), 139-153. https://doi.org/10.1080/13603111003671665

Koegel, L. K., Singh, A. K., \& Koegel, R. L. (2010). Improving motivation for academics in children with autism. Journal of Autism and Developmental Disorders, 40, 1057-1066. https://doi.org/10.1007/s10803-010-0962-6 
Leach, D., \& Duffy, M. L. (2009). Supporting students with autism spectrum disorders in inclusive settings. Intervention in School and Clinic, 45(1), 31-37. https://oi. org/10.1177/1053451209338395

Lindsay, S., Proulx, M., Scott, H., \& Thompson, N. (2014). Exploring elementary school teachers' strategies for including children with autism spectrum disorder in mainstream classroom classes. International Journal of Inclusive Education, 18(2), 101-122. https://doi.org/10.1080/13603116.2012.758320

Majoko, T. (2018). Practices that support the inclusion of children with autism spectrum disorder in mainstream early childhood education in Zimbabwe. International Journal of Special Education, 33(3), 630-656.

Mandell, D. S., Stahmer, A. C., Shin, S., Xie, M., Reisinger, E., \& Marcus, S. C. (2013). The role of treatment fidelity on outcomes during a randomized field trial of an autism intervention. Autism, 17(3), 281-295. https://doi.org/10.1177/1362361312473666

Pellecchia, M., Connell, J. E., Beidas, R. S., Xie, M., Marcus, S. C., \& Mandell, D. S. (2015). Dismantling the active ingredients of an intervention for children with autism. Journal of Autism and Developmental Disorders, 45(9), 2917-2927. https:// doi.org/10.1007/s10803-015-2455-0

Pugach, M. C., Mukhopadhyay, A., \& Gomez-Najarro, J. (2014). Finally making good on the promise of qualitative research in special education? A response to the special issue. Remedial and Special Education, 35(6), 340-343. https://doi. org/10.1177/0741932514545790

Reupert, A., Deppeler, J., \& Sharma, U. (2015). Enablers for inclusion: The perspectives of parents of children with autism. Australasian Journal of Special Education, 39(1), 85-96. https://doi.org/10.1017/jse.2014.17

Sakarneh, M. (2014). Jordanian education reform between the ideal and the actual. Developing Country Studies, 4(20), 65-73.

Sakarneh, M. (2016). The Applicability of the NSW Quality Teaching Model to the Jordanian primary school context. Dirasat: Educational Sciences, 43(Suppl. 4), 1773-1789.

Sakarneh, M. A., Sabayleh, O. A., \& Alramamneh, A. L. K. (2019). The sensory characteristics of children with autism spectrum disorder: Teachers' observation. International Journal of Early Childhood Special Education, 11(2), 105-115. https://doi.org/10.20489/intjecse.670459

Sakarneh, M. (2020). The challenges facing teachers in inclusion of students with special needs in the Jordanian basic schools from the teachers' point of view (in Arabic). Dirasat: Educational Sciences, 47(2), 90-102. 


\title{
Inkluzija učenika s poremećajem iz spektra autizma u redovna odeljenja u Jordanu: Perspektiva nastavnika
}

\author{
Mohammad Abed Sakarneha, Hiam Jameel Katanania, \\ Azeez Ahmad Alrahamneh ${ }^{\mathrm{b}}$ \\ a Al-Balka primenjeni univerzitet - Univerzitetski koledž Princeze Rahme, Al-Salt, Jordan \\ ${ }^{b}$ Al-Balka primenjeni univerzitet - Al-Salt koledž za humanističke nauke, Al-Salt, Jordan
}

Uvod: Ova studija je fokusirana na značaj uključivanja učenika s poremećajem iz spektra autizma (PSA) u redovna odeljenja. Ovo pitanje je steklo međunarodno priznanje s preporukama većine zemalja da ovim učenicima treba pružiti iste mogućnosti kao i onima bez ometenosti. Za ovo istraživanje odabran je slučaj jordanskih učitelja u Amanu. Cilj: Cilj istraživanja bio je da se ispita stanovište nastavnika o uključivanju učenika sa PSA u redovna odeljenja u Jordanu. Metode: Problem je ispitan primenom studije kvalitativnog dizajna, gdje je virtualno intervjuisano devet nastavnika. Rezultati: Nalazi su ukazali na potrebu za boljom obukom i razvojem veština o određenim aspektima i potrebama učenika sa PSA. Obezbeđivanje obuke za nastavnike, kao i materijane i finansijske podrške neophodni su za podržavanje inkluzivnog učenja. Nastavnici su takođe izvestili o značajnim ograničenjima u pogledu načina na koji se podržava inkluzija učenika sa PSA u Jordanu. Kada je reč o inkluziji učenika sa PSA u Jordanu, njihovi nastavnici, zbog neadekvatne obuke i nedovoljnog iskustva, imaju manjak samopouzdanja i nisko vrednuju vlastite sposobnosti za rad sa ovim učenicima i organizovanje inkluzivnog razreda. Zaključak: Nalazi ove studije ukazuju na potrebu da kreatori politike u Jordanu razmotre mogućnost pružanja posebne obuke svojim nastavnicima specijalne edukacije.

Ključne reči: poremećaj iz spektra autizma, inkluzivno obrazovanje, redovna odeljenja, nastavnička perspektiva 